\title{
Obligatory amateurs: Annie Maunder (1868-1947) and British women astronomers at the dawn of professional astronomy
}

\author{
MARILYN BAILEY OGILVIE*
}

\begin{abstract}
This paper explores the careers of several British women astronomers in the late nineteenth and early twentieth centuries. I postulate that the only category of scientific practice open to most of these women was that of an 'amateur'. They would have become professionals had they had the opportunity but since they were barred from professional status they used their talents to promote the importance of amateur science. I propose the term 'obligatory amateur' for these women who, unlike men, were unable to choose amateur or professional status. I explore this concept of a 'gendered' amateurism through the life and works of Annie Maunder, with references to British women astronomers contemporary with her.
\end{abstract}

Although historians of science usually agree on the dangers of using terms such as 'amateur' and 'professional' indiscriminately in their writings, there are still some occasions when the labels can be useful. Notions about what constitutes an 'amateur', for example, are particularly relevant when investigating the roles of enthusiasts for whom science was a vocation rather than a livelihood. Long ago, David Allen's Naturalist in Britain established that while professionalization galloped ahead in the second half of the nineteenth century, amateurs continued to thrive in the observational sciences such as botany and ornithology. As many scholars have indicated, this was a complex, reciprocal process subject to continued negotiation. Yet it is clear that as the nineteenth century waned, the sciences in general retreated from a situation where amateur and professional shared common scientific goals and reaped similar benefits. Amateurs became increasingly restricted to certain types of activity whereas professionals-however they might be defined - were free to tackle and presumably conquer the more vexing scientific tasks. Professional status was increasingly denied to many people for various reasons (including their own preference for amateur status). But the opportunity to become professional was very nearly closed to one notable group, namely women. ${ }^{1}$

\footnotetext{
* History of Science Collections, University of Oklahoma, 401 West Brooks, Room 521, Norman, Oklahoma 73019-0528, USA.

1 A selection of relevant works not noted elsewhere in this paper include R. Cooter and S. Pumfrey, 'Separate spheres and public places: reflections on the history of science popularization and science in popular culture', History of Science (1994), 237-67; D. E. Allen, 'The early professionals in British natural history', in From Linnaeus to Darwin: Commentaries on the History of Biology and Geology. Papers from the Fifth Easter Meeting of the Society for the History of Natural History (ed. A. Wheeler and J. H. Price), London, 1983; S. Collini, Public Moralists: Political Thought and Intellectual Life in Britain, 1850-1930, Oxford, 1991; D. S. L. Cardwell, The Organisation of Science in England. A Retrospective, London, 1957; M. Rothenberg, 'Organization and control:
} 
In this paper I examine the life stories of several British women living in the late nineteenth and early twentieth centuries, who were keen and talented astronomers. I suggest that the only category of scientific practice open to most of these women was that of an 'amateur'. They would have become professionals if the opportunity had been present. Barred from professional status, they used their skills to promote the usefulness of amateur science. I propose the term 'obligatory amateur' for these women who, unlike men, were unable to choose amateur or professional status. I will explore this concept of a 'gendered' amateurism through the life and works of Annie Maunder (née Russell) with references to British women astronomers contemporary with her.

\section{Obligatory amateurs}

Annie Russell Maunder was as professional as any woman astronomer could have been in the late nineteenth century. She held the equivalent of a Cambridge University degree; women were allowed to take the examinations, but were not eligible for titular degrees until 1923 and could not become full members of the University until 1948, the year after her death. She held a paid position at the Royal Greenwich Observatory. She published numerous papers, some popular, some technical and some theoretical. She became a member of professional societies. However, during her life she operated on the margins of professional astronomy and, along with her husband Edwin Walter Maunder (1851-1928), was a vocal advocate of the importance of the amateur tradition. It seems clear that the primary factor operating to exclude Maunder from professional life was her gender. But other issues, too, such as the divided professional and personal lives of women in science, the revolutionary change in women's access to higher education and the importance of collaboration with a spouse conspired to make Annie Maunder an obligatory amateur

Maunder was just one among several British women of the nineteenth and early twentieth centuries who was consigned to amateur status. Historians Steven Shapin and Arnold Thackray's scheme for dividing the British scientific community into three levels works well here. Some British women astronomers belong in the first level - those who published one or more works concerned with natural phenomena. Others can be placed on the second tier - those who did not publish but associated themselves with a scientifically oriented society or institution, or disseminated knowledge to others. The third group,

professionals and amateurs in American astronomy, 1899-1918', Social Studies of Science (1981), 11, 305-25; P. L. Farber, The Emergence of Ornithology as a Scientific Discipline, 1760-1850, Dordrecht, Holland, 1982; A. B. Shteir, 'Botany in the breakfast room: women and early nineteenth-century British plant study', in Uneasy Careers and Intimate Lives: Women in Science 1789-1979 (ed. P. Abir-Am and D. Outram), New Brunswick, CT, 1987, 31-43; J. Lankford, 'Amateurs versus professionals: the controversy over telescope size in late Victorian science', Isis (1981), 72, 11-28 (12); M. W. Rossiter, Women Scientists in America: Struggles and Strategies to 1940, Baltimore, 1982 (p. xv). Alex Soojung-Kim Pang's work is especially relevant. He described ways in which culture and national scientific styles depict the types of opportunities available to women. By using three astronomers as examples, two Americans (Elizabeth Campbell and Mabel Loomis Todd) and one British (Annie Maunder), he defined the range of opportunities available for women to participate in eclipse expeditions. A. Pang, 'Gender, culture, and astrophysical fieldwork: Elizabeth Campbell and the Lick observatory - Crocker eclipse expeditions', Osiris (1996), 11, 15-43. See also Pang, 'The social event of the season: solar eclipse expeditions and Victorian culture', Isis (1993), 84, 252-77. 
those who 'neither published science, taught science, nor actively associated themselves with scientifically oriented institutions', ${ }^{2}$ but whose interests included attending lectures, reading popular books and engaging in discussions of scientific matters, will not be considered. Although I will allude to some women who belonged to the second group, most will be Annie Maunder's scientific peers - women who published papers or books on astronomical subjects - the obligatory amateurs.

During the nineteenth century, before professionalization overshadowed the freewheeling amateurs, it was common to find women participating in observational astronomy. This tradition was retained at some level even after professionalization became more important. One of these nineteenth-century women, Agnes Mary Clerke (1842-1907), in her book A Popular History of Astronomy during the Nineteenth Century, extolled the virtues of the 'new physical astronomy' when she wrote that 'it is, in a special manner, the science of amateurs'. Although she did not specify women amateurs, she went on to say that "there is no one "with a true eye and a faithful hand" but can do good work in watching the heavens'. ${ }^{3}$ Even though, as Clerke noted, the 'new astronomy' was suitable for amateurs and many important discoveries were made by them, the trend towards professionalization increased relentlessly and the scope for amateurs narrowed. ${ }^{4}$ It is evident that women were indeed participants in 'the science of amateurs', but as professional standards were enforced, most women astronomers remained outside. Although a few women achieved professional status, gender-exclusive professional organizations and a lack of educational opportunities made it very difficult for women to obtain professional status. Unlike in many other sciences, amateurs in astronomy maintained their position within the astronomical community - a status they retain even today. ${ }^{5}$ The research of amateurs continued to be useful to the new professionals. ${ }^{6}$

Irish astronomers Margaret Huggins (1849-1915) and Agnes Mary Clerke, and English astronomer Mary A. Blagg (1858-1944) are all examples of women who published in astronomy and who, given different opportunities, might have become professionals. These three women and Maunder had in common a lack of persistent domestic responsibilities. Although Clerke and Blagg remained unmarried, both Maunder and Huggins married older, established astronomers as did Maunder's later contemporary, English astronomer

2 S. Shapin and A. Thackray, 'Prosopography as a research tool in history of science: the British scientific community 1700-1900', History of Science (1974), 12, 1-28, (12-13). For additional works on professionalization, see A. Thackray, 'Natural knowledge in cultural context: the Manchester model', The American Historical Review (1974), 79, 672-709; N. Reingold, 'Definitions and speculations: the professionalisation of science in America in the nineteenth century', in The Pursuit of Knowledge in the Early American Republic: American Scientific and Learned Societies to the Civil War (ed. A. Oleson and S. C. Grown), Baltimore, 1976, 33-69; M. Crosland, 'The development of a professional career in science in France', in The Emergence of Science in Western Europe (ed. M. Crosland), New York, 1976; J. Ben-David, The Scientist's Role in Society: A Comparative Study, Englewood Cliffs, NJ, 1971.

3 A. M. Clerke, A Popular History of Astronomy During the Nineteenth Century, 4th edn., London, 1908, 5.

4 See Clerke's articles on the history of astronomy in the 11th edn. of the Encyclopaedia Britannica, Cambridge, 1910

5 Consider the discovery of comet Shoemaker-Levy, for example.

6 Popular astronomy had many faces. Although most work by amateurs was observational, certain theoretical topics attracted popular treatment. See, for example, M. J. Crowe, The Extraterrestrial Life Debate, 1750-1900: The Idea of a Plurality of Worlds from Kant to Lowell, Cambridge, 1988. 
Mary Orr Evershed (1867-1949). None of the women mentioned above had children of their own, although Maunder helped raise her husband's two daughters from a previous marriage. The common factor in their success seems to have been an early interest in astronomy and a supportive intellectual atmosphere at home. The three married women were interested in astronomy long before their marriages, and the two unmarried women were also preoccupied with astronomy at an early age. Unquestionably, the reputations of their husbands, the astronomers Edward Walter Maunder, William Huggins (1824-1910), and John Evershed (1864-1956), made it easier for their wives to become marginally accepted by the astronomical community, but the examples of Clerke and Blagg make it equally clear that women astronomers did not need influential spouses to be successful. Nevertheless, collaboration served as a successful strategy for Maunder, Huggins and Evershed. In Annie Maunder's case, Walter's involvement in amateur astronomy spurred her already active interest in the area.

Huggins (née Murray), Maunder, Clerke, Blagg and Evershed (née Orr) all came from families sympathetic to a child's intellectual interests, although the extent of their formal education varied. Blagg attended a private boarding school in London but was basically self-taught in astronomy and mathematics. Huggins, Evershed and Clerke were educated at home. Introduced to observational astronomy by her grandfather, Huggins read widely in astronomy and constructed a spectroscope using a plan from the magazine Good Words. William Huggins continued her astronomical education and soon Margaret was capable of making her own contributions. Evershed's formal education was minimal, but as a young person she read widely and travelled to Australia, Germany and Italy. During her time abroad, she became interested in astronomy. This pursuit was encouraged when she married astronomer John Evershed. Agnes Mary Clerke was also educated at home and, like Huggins and Evershed, showed an early interest in astronomy. It was Clerke's father, a bank manager and amateur astronomer, who interested his two daughters in the subject. Like Evershed, Clerke's family spent time abroad. Annie Maunder was the only one of the five women to have the equivalent of a university education. As a student at Girton College, Cambridge, she earned the title senior optime in the mathematical tripos. ${ }^{7}$

These women (and others) had a considerable amount of expertise and in another time and under different circumstances might well have become professionals. However, they all played an important role in strengthening the British amateur tradition through their popular works and their support of those scientific societies that catered to amateurs. All were active participants in the activities of the British Astronomical Association (BAA); they took part in its eclipse expeditions, participated in observational sections, served on the BAA council and edited its journal. Although Annie Maunder had many characteristics in common with other British women astronomers, she was especially influential because of her university education and the passionate commitment of her husband, Walter, to amateur astronomy. Maunder's life and work serves as a helpful case study.

7 For biographical details see M. B. Ogilvie, Women in Science: Antiquity through the Nineteenth Century: A Biographical Dictionary with Annotated Bibliography, Cambridge, MA, 1986. See also Mary Brück, 'Companions in astronomy: Margaret Lindsay Huggins and Agnes Mary Clerke', The Irish Astronomical Journal (1985), 20, 70-7. Barbara Becker is completing a comprehensive study on Margaret Huggins, and Bernard Lightman is working on Agnes Clerke. 


\section{Early life and education}

Annie Maunder's interest in astronomy extended back at least as far as her years at Girton College, Cambridge. It may have reached back to her early years in Ireland, for her brother Dr J. Dill Russell also became an astronomer. Born in Strabane, County Tyrone in the north of Ireland, Annie was the elder daughter of the Reverend William Andrew Russell and his second wife Hester Nesbitt (née Dill). ${ }^{8}$ The family was large, for there were two sons from her father's first marriage and two sons and two daughters from his second. Her early education at home and at the Ladies' Collegiate School, Belfast (renamed the Victoria School and College) left her unprepared for the rigorous courses at Girton College, where she matriculated in $1886 .{ }^{9}$ W. H. Young, Esq., a Fellow of Peterhouse under whom Annie read mathematics, wrote that she was 'more than ordinarily handicapped - even for a woman - by an insufficiency of preliminary training ${ }^{10}{ }^{10}$ Russell, like most Girton 'freshers', entered enthusiastically into the routine: 'prayers at eight, breakfast from eight to nine, study hours from nine to one, lunch when you like between twelve and three, noise hours from one to three, dinner at six, study hours again from half-past seven to nine, and then noise hours again from nine until half-past ten'. ${ }^{11}$

Girton, a women's college, was founded just seventeen years before Russell matriculated. Women were allowed to take the University examinations, but were not eligible for titular degrees until 1923. From this time on, various ordinances were passed regularizing the position of women within the University. ${ }^{12}$ By working extraordinarily hard, Annie Russell managed to score well enough on her mathematical tripos to obtain the high place of a senior optime when she graduated in $1889 .{ }^{13}$

Astronomy was an improbable vocational choice for both men and women, for at that time it was taught as a part of mathematics and mathematical physics. ${ }^{14}$ However, for a woman at Cambridge the barriers were especially formidable. When Russell was at Girton, Cambridge University itself had been undergoing radical curricular changes, particularly in the sciences. Because it lacked the money to endow research and because its relationship with the University was weak, Girton was only mildly influenced by the new spirit. Girton alumnae, aware of its weakness, established several prizes (one of which Annie Russell

8 College Register, Girton College, 1869-1946, Cambridge, 1948, 1886. Although much information is available on Walter Maunder acting as Annie's mentor, little is known about her brother J. Dill Russell acting in the same fashion.

9 M. T. Brück, in 'Alice Everett and Annie Russell Maunder: torch-bearing women astronomers', Irish Astronomical Journal (1993-4), 21, 281-90, 281-2, notes that Russell, after leaving this school, did not go on for an Irish university degree. Instead, she sat for the Girton open entrance examination after having won a prize in the public Irish Intermediate examination in 1886. She was awarded an annual scholarship for three years.

10 Recommendation, W. H. Young, Esq., MA Fellow of Peterhouse, Cambridge. Royal Greenwich Observatory Archives 7/14. Hereafter cited as RGO.

11 'Life at Girton, 1888', King's High School Warwick, 1879-1979, 25-7. Girton College Archives.

12 B. Stephens, Girton College, 1869-1932, Cambridge, 1933, 111, 118, 130.

13 Russell's position was described as senior optime (between brackets 41 and 43). Girton Review, July 1889 , Examination Lists, 8. In the Cambridge University Reporter for 1889, the male degree recipients were listed. In the list of senior optimes, two men were bracketed in place 42 and four in place 43. Cambridge University Reporter, Mathematical Tripos, Part I (1889), 826. Girton College Archives.

14 See P. A. Kidwell, 'Women astronomers in Britain, 1780-1930', Isis (1984), 75, 534-46 for a discussion of the education of would-be astronomers. 
later received) and studentships to help the College achieve University admission standards. The new awards were of little help to women already wanting to pursue careers in astronomy.

Russell surmounted the first hurdle by taking the mathematical tripos, but her gender would have thwarted the next requirement - an apprenticeship as an assistant at a major observatory. When she and her fellow senior optime, Alice Everett, donned their scarlet robes at noon on Tuesday, 11 June 1889, for the 'Recitation of Prize Exercise', they both were interested in astronomy but had no illusions about career possibilities. ${ }^{15}$ Everett was hired by the Royal Greenwich Observatory as a mere 'computer'. When Russell left Girton, however, she took a position as a mathematics teacher at the Ladies' College, Jersey, with a salary of eighty pounds per year with residence included. ${ }^{16}$

\section{The Royal Observatory, Greenwich}

Russell found school teaching faintly disagreeable, and when she learned of a possible vacancy for a 'lady computer' at the Royal Greenwich Observatory (RGO), she saw an opportunity to rid herself of teaching while pursuing the career in astronomy that she coveted. During the early 1890s, the Observatory experimented with hiring women computers. Unlike the teenaged boys whom they replaced, only women who had completed the equivalent of a bachelor's degree were hired. The women were hired by the Astronomer Royal, W. E. Christie, as 'supernumerary' computers, that is, computers in addition to the original eight. ${ }^{17}$ In addition to allowing educated women an opportunity to work in astronomy (although it was mostly routine work at a menial salary), the system had an advantage over the previous one. Formerly, boys were recruited at the age of fourteen and discharged when they were about twenty-three years old, at which time the young men found that

the mathematics and kindred subjects which have been acquired in this period become absolutely

useless, as men are not wanted in the market unless having had a good business experience. So

they swell the already overcrowded unskilled labour multitude. This rotten system seems to be maintained by Government solely to save money. ${ }^{18}$

Hiring women for these positions seemed to be an ideal solution for the Observatory, for young women with astronomical aspirations flocked to apply for the underpaid positions. Late in 1891 the Observatory secretary, H. H. Turner, wrote to Miss C. Elder, asking her to evaluate the success of the programme, which

has now been in progress for nearly two years and you will be able to learn how far it is successful from the point of view of the ladies,...from Miss Everett or Miss Rix, who have been here throughout.

He also requested her help in recruiting another woman for a vacancy. 'The work would be more particularly suitable for those enthusiastic about science than for those to whom

15 Cambridge University Reporter, June 8, 1889, 827.

16 Kidwell, op. cit. (14), 536-7; Annie Scott Dill Russell (Maunder) to H. H. Turner, Secretary, Royal Greenwich Observatory, n.d. [1891]. RGO 7.

17 Brück, op. cit. (9), 282.

18 A. J. Meadows, Greenwich Observatory. The Royal Observatory at Greenwich and Herstmonceux, 1675-1975, 3 vols., London, 1975, ii, 14. 
salary is a consideration of the first importance'. The salary, he informed her, would begin at four pounds a month and increase to six pounds as 'soon as efficiency in the use of the Photographic Equatorial is acquired'.$^{19}$

Russell found out about this forthcoming vacancy at the Observatory through her friend, astronomer Alice Everett, and promptly wrote to Turner with information gleaned from Everett that 'there will probably be a vacancy soon for a Lady Computer at Greenwich Observatory'. ${ }^{20}$ Although her recommendations were excellent (Miss Welsh, Mistress of Girton College, praised her 'diligence, intelligence, and conscientiousness' as a student), Russell received Turner's standard reply: 'the Astronomer Royal requests me to inform you that he does not propose to consider the appointment of any other lady computers at present, but that when the occasion arises he will communicate with you'. ${ }^{21}$

Russell, however, was persistent. Her father even requested a letter of recommendation from Robert Ball, FRS, on her behalf. ${ }^{22}$ This letter proved unnecessary, for Turner offered her the job before Ball's letter arrived. The terms of the offer were a bit disconcerting, for the salary of four pounds a month 'is so small that I could scarcely live on it'. She asked if the fact 'that I have taken the Mathematical Tripos at Cambridge makes no difference' ?23 Relaying Christie's words, Turner replied that the 'salary offered you is simply dictated by our own finances and must not be considered in any way to appraise your attainments' ${ }^{24}$ Russell did not attempt further negotiation, and after she 'carefully considered the subject' she 'decided to accept the post at Greenwich Observatory'. ${ }^{25}$

A precedent for the Greenwich Observatory's policy of hiring low-paid women computers had been established at the Harvard College Observatory. During the tenure of Joseph Winlock, the third director, one or two women applied as student assistants, but apparently none actually appeared. However, under E. C. Pickering (Director, 1876-1919), the Harvard Observatory began a policy of admitting women to its staff. The Harvard experiment was very successful, for excellent talent could be obtained very cheaply. ${ }^{26}$ In contrast, the Greenwich experiment with women computers was short-lived. The archives are unclear as to why Greenwich discontinued the policy of hiring women which, on the surface, seemed beneficial to the institution. What is very clear, however, is that through the first decades of the twentieth century women who wanted professional positions in astronomy found them almost impossible to attain. A Finnish woman, Anna Molander, expressed her desperation to Turner:

I am looking for an appointment in some girls' school as a teacher and lecturer in Astronomy and History of Astronomy and Nature Study... and the Principals inform me that Astronomy and Nature study is not required in the curriculum by the examiners. I have studied The Nature and The Heavens from the polar circle to the equator but that is a study that does not count much in 'the struggle for life'.

19 H. H. Turner to Miss C. Elder, 22 December 1891. RGO 7.

20 Russell (Maunder) to Turner, 13 January 1890. RGO 7.

21 Turner to Russell (Maunder), 31 January 1891. RGO 7.

22 Robert Ball, FRS, to W. E. Christie, 29 July 1891. RGO 7.

23 Russell (Maunder) to Turner, n.d. RGO 7.

24 Turner to Russell (Maunder), 28 July 1891. RGO 7.

25 Russell (Maunder) to Turner, 30 July 1891. RGO 7.

26 B. Z. Jones and L. G. Boyd, The Harvard College Observatory; The First Four Directorships, 1839-1919, Cambridge, MA, 1971, 386. 
She further explained that she had been in America and had written to Pickering for information about employment at the Harvard College Observatory. He had sent her an application which she did not return, because 'I would most likely be put to some drudgery under Mrs. Fleming [Williamina Paton Fleming]'. She recognized that in a Royal Observatory, 'the Civil Service predominates, so there is no use for me to aim at that even if women were accepted for such posts in England as they are in America'. After stating her qualifications for jobs in private observatories, she again asked Turner for his help. His response was an unequivocal 'no'. ${ }^{27}$

As meagre as was the financial remuneration for her position at Greenwich, the shortlived policy compensated Annie Russell in an unexpected way. At the RGO she met widower Walter Maunder, First Assistant for Photographic and Spectroscopic Observations. Maunder had been disaffected with the Observatory from the beginning of his Civil Service appointment in 1873. The arbitrary, dictatorial Astronomer Royal, G. B. Airy, never liked Maunder personally and intentionally tried to make him uncomfortable. For example, he demanded that 'W. Maunder... bring to...[him] at 10 o'clock every morning the whole of the photographical plates and other work on which he has been employed on the preceding day, and to have a written statement of the work prepared for the current day'. ${ }^{28}$ In addition to personal animosity, Airy was not sympathetic towards Maunder's research into solar phenomena, because it involved the new astrophysics which he had only unwillingly accepted at the Observatory.

Although the situation improved under W. E. Christie, Walter Maunder was passed over for promotion time and time again. In desperation he applied for the vacant position of Astronomer Royal of Scotland, writing that

there is now no possibility for me of further advancement at Greenwich; and even the possibility of my usefulness is curtailed. I therefore wish if possible to leave this Observatory, and the thought has suggested itself to me; - Would it be possible for me to succeed Dr. Copeland at Edinburgh ? ${ }^{29}$

F. W. Dyson was selected for the Edinburgh position, to Maunder's disappointment.

At Greenwich, Annie Russell was responsible for examining and measuring the daily sunspot photographs. Walter Maunder was head of the solar photography department, and he and Annie became friends as well as colleagues. It is probable that because of her friendship with Maunder, she was more than 'merely' a computer in that he taught her to use the photographic equatorial. He had been involved in keeping systematic observational records of various sunspot features such as number, area, changes, position and motion since 1874. Drawing on both accumulated records and her own measurements, Annie postulated in an article published in 1907 that there is 'an apparent influence of the earth on the numbers and areas of sun-spots'. She proposed that the decrease in sunspot frequency as spots appear to pass from east to west on the Sun's disk is probably not an intrinsic solar phenomenon, but 'apparently' only a terrestrial illusion. However, she concluded that 'it is quite conceivable that there may be some physical characteristic of sun-spots, purely solar in its nature, which renders them more easily visible when they are

27 A. Molander to Turner, 23 June 1909. RGO 7.

28 Memo from G. B. Airy, 30 April 1875. RGO 6.

29 E. W. Maunder to Sir David Gill, 2 April 1896. RGO 15. 
approaching us than when they are receding'. Although her opinion that the difference in number and area of sunspots is only apparent is accepted today, the explanation that she approved, that sunspots are holes in the photosphere, was refuted afterwards. ${ }^{30}$

Annie Maunder's sunspot paper merited a summary of over a page in the Astronomischer Jahresbericht of 1908. This publication abstracts the astronomical papers published each year, and the abstract of Maunder's work was longer than the average, indicating that it was considered significant at the time. ${ }^{31}$ Another indication of the importance of the paper is a reference in a respected German textbook, in which in the historical account of the decrease in sunspot numbers from east to west, Annie Maunder's theory is described first. ${ }^{32}$ The reception of Maunder's paper establishes that her work was of similar calibre to that of professional male astronomers.

Shortly after her marriage to Walter in 1895 , Annie Maunder received a newly created award, the Pfeiffer Research Student Fellowship, established as an attempt to upgrade the Girton College research potential. As the first recipient of this fellowship (1896), Maunder used the money to make a photographic study of the Milky Way. ${ }^{33}$ For this study she used a 'Dallmeyer stigmatic lens' with a one-and-a-half-inch aperture and nine-inch focal length. ${ }^{34}$

Annie Russell's career received an undoubted boost when she married Walter Maunder. Although there has been an increasing awareness of the importance of 'scientific marriages' to the history of women in science, studies such as the essays in Uneasy Careers and Intimate Lives (1987) have focused more on the interplay between personal life and career. However, a new collection of essays, Creative Couples in the Sciences, explores the practice of collaboration and its implications for the work and careers of both partners. ${ }^{35}$ Within the context of 'scientific couples', Annie Russell's marriage to Walter Maunder proved fortuitous, for through him she was able to have instruments made available, and to have contacts with other astronomers and opportunities to travel to various eclipse sites. Not only were the accoutrements of professional astronomy available to Annie Maunder, but she also acquired a husband who thought women had an important place in astronomy.

\section{Walter Maunder and the formation of the British Astronomical Association}

Since membership of professional societies is recognized by most historians as a requisite for professional status, it is interesting to note that the course of Walter Maunder's career provided Annie with an accepted outlet for her scientific publications. This channel was the

30 A. S. D. Maunder, 'An apparent influence of the Earth on the numbers and areas of sun-spots in the cycle 1889-1901', Monthly Notices of the Royal Astronomical Society (1907), 67, 451-75; M. A. Evershed, 'Mrs. Walter Maunder', The Journal of the British Astronomical Association (1946-7), 57, 238.

31 'Die Literatur des Jahres 1907', Astronomischer Jahresbericht, Berlin, 1908, 370-1.

32 M. Waldmeier, Ergebnisse und Probleme der Sonnenforschung, Leipzig, 1955, 160.

33 Stephens, op. cit. (12). There is no evidence as to why Maunder chose the Milky Way as the subject of her project.

34 A. S. D. Maunder, 'Eclipses I have seen', Chaldean (1927), 7, 4-16.

35 H. M. Pycior, N. G. Slack, and P. G. Abir-Am (eds.), Creative Couples in the Sciences, New Brunswick, NJ, 1996. 
British Astronomical Association, established in 1890 by Maunder himself. Maunder for some time beforehand had been displeased with the direction he perceived that the Royal Astronomical Society was taking, although he was elected a Fellow in 1875 and later served as a council member and secretary. At the beginning of the nineteenth century, when the Royal Astronomical Society was first established, the distinction between professional and amateur had been conveniently blurred. Among those who attended the first organizational meeting, John Herschel and Francis Baily had made names in astronomy, but twelve others were clearly amateurs in the eighteenth-century usage of 'one who loves' an activity. The first nominal president of the Society was Sir William Herschel $;{ }^{36}$ the second president was an amateur in the latter sense, H. T. Colebrooke, a Sanskrit scholar who was interested in Brahman knowledge in mathematics and astronomy. That the organization was originally inclusive was apparent in one of the resolutions at the organizational meeting. This resolution stated that all interested individuals who were recommended by a present member were invited to join the new organization. ${ }^{37}$

In the decade between 1830 and 1840, telescopes were not yet common among the members of the Society, even though its amateur members were serious about astronomy. William Parsons, third Earl of Rosse, was an exception, for he owned a powerful telescope. In the 1830s he experimented with large mirrors and in the following decade constructed a large reflecting telescope powerful enough to discredit temporarily the nebular hypothesis. He demonstrated that many of the nebulae formerly thought to be irresolvable could be resolved into their component stars. ${ }^{38}$

Although when Walter Maunder became a Fellow of the Royal Astronomical Society amateurs were recognized as important contributors to the organization, their status was gradually diminishing in the face of professionalization. Women were excluded from the Society until $1915 .^{39}$

Unhappy both in his job and with the Royal Astronomical Society, Walter Maunder found an alternative way to display his talents. First of all, he edited the Observatory Magazine, which included the works of astronomers who belonged to the Liverpool Astronomical Society and was closely related to the RGO. The Liverpool Astronomical Society welcomed amateurs, including women, and was known for the 'section' model, with each section headed by an experienced observer. However, by 1890 many of the members were disaffected, including Elizabeth Brown, Director of the Solar Section, who wrote several letters to Walter Maunder advocating the establishment of a new society. ${ }^{40}$ A series of articles in the English Mechanic followed, arguing the need for a new

36 Herschel was not educated as an astronomer, but what began as a hobby soon occupied so much of his time that he could almost be considered a professional.

37 J. L. E. Dreyer, History of the Royal Astronomical Society: 1820-1920, London, 1923, 1-3.

38 M. B. Ogilvie, 'Robert Chambers and the nebular hypothesis', British Journal for the History of Science (1975), 8, 214-32, 218. See also William Parsons, third Earl of Rosse, 'On the construction of large reflecting telescopes', Report of the British Association for the Advancement of Science (1844), 79-82; and 'Observations on some of the nebulae', Philosophical Transactions of the Royal Society of London (1844), 134, 321-4.

39 Parsons, op. cit. (38).

40 R. McKim (ed.), The History of the British Astronomical Association: The First Fifty Years, 2nd edn., London, 1989, 7. 
organization based on the section model. ${ }^{41}$ Walter Maunder became the driving force behind the new organization. The British Astronomical Association was established 'to meet the wishes and needs of those who find the subscription of the RAS too high or its papers too advanced, or who are, in the case of the ladies, practically excluded from becoming fellows' ${ }^{42}$ In short, since astrophysics did not require a strong mathematical background or, at least in its early stages, expensive equipment, Walter Maunder's interests coincided with those of many amateurs. Maunder coped with the problem by forming an inclusive new society.

The BAA was formed the year before Annie Russell was hired at Greenwich, and so the organization of the society was well under way by the time she became involved. At the RGO, she was assigned to help Walter with his solar observations and, most probably, heard all about the new organization. At any rate, her enthusiasm about the organization's potential equalled Walter's. She became the first editor (1894-6) of the Journal of the British Astronomical Association before she married Walter in 1895. She served as editor again from 1917 to 1930 but refused to accept the presidency of the organization because 'of her voice, which would not carry in a large room'. ${ }^{43}$

In spite of the BAA's acceptance of women, no woman became president in the history of the organization until Heather Couper (1984-6) was elected. The first woman secretary was Annie Maunder's Girton friend, Alice Everett, who was secretary from 1893 to 1896. In 1924 a Miss E. W. Clack became secretary, apparently to fill the gap between the terms of E. Prentice and Reverend F. C. Lees. The three women who became secretaries in later times were Mrs G. E. Stone (1972-6), Miss E. R. Atwell (1987) and Mrs H. McGee (1988) ${ }^{44}$ The office of assistant secretary was established in 1931. Of the eight individuals who have held the position since that year, five have been women. ${ }^{45}$ During the first fifty years of the Association, only four women were section chairs. Elizabeth Brown chaired the Solar Section from 1890 to 1899. Two women chaired the Meteor Section: C. O. Stevens from 1905 to 1911 and A. Grace Cook from 1921 to 1923. Mary Evershed chaired the Historical Section from 1930 to $1944 .{ }^{46}$ The dearth of women holding offices in the BAA does not reflect their importance to the organization and the organization's importance to them. Their names and accomplishments are scattered throughout the two volumes of the history of the organization. Throughout the history of the BAA, the achievements of women members were comparable to those of the men, illustrating that this organization was an effective outlet for amateurs. Other women from overseas, who may or may not

41 English Mechanic and World of Science (18 July 1890), 445-6; (25 July 1890), 462-3; (1 August 1890), 487-8; (8 August 1890), 512-13; (15 August 1890), 527-8, Archives, British Astronomical Association, hereafter BAA Archives. The following sections were headed by experienced observers: Solar, Solar Spectroscopic, Lunar, Mercury and Venus, Mars, Jupiter, Saturn, Comet, Meteor, Photographic, Aurora and Zodiacal Light, Variable Star, Double Star, Star Colour, Methods of Observation, Computing, Historical, and Library. See McKim, op. cit. (40), 238.

42 Deborah Jean Warner, 'Edward Walter Maunder', Dictionary of Scientific Biography 9, 183-5, 184.

43 Evershed, op. cit. (30), 238.

44 The secretaries in the later years had specific functions - for business, papers and meetings.

45 McKim, op. cit. (40), 131 and idem, The History of the British Astronomical Association. The Second Fifty

Years, London, n.d., 119-21.

46 McKim, op. cit. (40), 65, 125. 
have been members of the association, also gave lectures for various meetings. ${ }^{47}$ Some of these British women undoubtedly would have chosen to do what was necessary to become professional if it had been an option for them.

\section{Professional service in amateur settings: BAA eclipse expeditions}

The BAA eclipse expeditions represented clear examples of the similar types of astronomical work in which men and women were engaged. The eclipsed Sun presented problems that intrigued astronomers, both amateur and professional, in the last decade of the nineteenth century and the first part of the twentieth. Many separate expeditions sponsored by different organizations were launched to sketch, photograph and collect solar data. Annie was involved with Walter in the BAA's eclipse expeditions, which were mounted partially because of the less than satisfactory treatment Walter received from the Royal Greenwich Observatory. Although Walter was a member of the Joint Permanent Eclipse Committee (Royal Astronomical Society and Royal Society), he perceived that the Observatory either provided him with inferior equipment or sent him to poor observing locations. ${ }^{48}$

The first BAA expedition was to Vadsø Island, Norway, to view the 9 August 1896 total solar eclipse. Fifty-eight people, all of whom paid their own way, were a part of the eclipse party. Although 'it was unfortunate in the weather conditions on the day of the eclipse and consequently without those scientific fruits which had been hoped from it, it was most successful in every particular which depended on the members themselves'. Annie operated the four-inch coronograph with her brother, astronomer Dr J. Dill Russell. The latter revolved the drum 'whilst Mrs Maunder effected the exposures' ${ }^{49}$

One of the most important indirect effects of the Vadsø expedition was to strengthen the young Association, impressing on it 'an increased sense of its own power for usefulness, and it brought it into prominence before the public'. The result was 'a considerable increase in the membership of the Association; in greatly promoting the union of the members; and in the creation and cementing of many friendships which promise to be lifelong, ${ }^{50}$

When the time came for the Association to make plans for the India eclipse of 22 January 1898 , it naturally hoped to arrange it in much the same way. But an outbreak of plague forced them to change their plans. The group, therefore, divided into two sections, one

47 For example, Annie Jump Cannon of the Harvard Observatory gave several lectures at the BAA. In 1909, she spoke on spectral types and variable stars. She returned in 1925 when she spoke to the International Astronomical Union describing work done on the Henry Draper Catalogue of Stellar Spectra. McKim, op. cit. (40), 19, 35-6. Mary Proctor spoke in 1914 about a proposed solar observatory in New Zealand. McKim, op. cit. (40), 21. In 1933, Cecilia Payne of Harvard College Observatory gave an account of her work on Wolf-Rayet stars. McKim, op. cit. (40), 39.

48 A. S. D. Maunder to Captain Molesworth, 14 September 1900. Archives of the Royal Astronomical Society. Hereafter RAS Archives. Molesworth 1, folio 2, letter 4.

49 E. W. Maunder, 'Expedition for the observation of the total solar eclipse, August 9th 1896', Memoirs of the British Astronomical Association, Reports of the observing sections, (1898), 6, 1-20; idem (ed.) The Indian Eclipse, 1898. Report of the expeditions organized by the British Astronomical Association to Observe the Total Solar Eclipse of 1898, January 22', London, 1898, 1.

50 Maunder, Indian Eclipse, op. cit. (49), 1. 
going to Talni (the Maunders were a part of this group) and the other to Jeur. One of the scientific goals of the expeditions was to photograph 'for the first time some of the faint extensions of the corona'. However, the day was 'an exceptionally bright one, much brighter than the brightest night at the full of the moon'. ${ }^{51}$

The photographs taken by Annie Maunder on this expedition support the contention that whereas her work was respected by professionals, she was given more credit than many amateurs because she was married to Walter. ${ }^{52}$ She designed her own equipment combination, which consisted of a small camera with a Dallmeyer photographic lens (the one she had used for her study on the Milky Way) carried by a Waters Equatorial loaned to Walter Maunder by the Royal Astronomical Society. Other borrowed equipment included an additional camera attached to the equatorial and a telephoto lens. The results were spectacular. She achieved her goal of photographing the longest possible extension of the coronal streamers. When she presented the photographs to the British Astronomical Association, her results were greeted by loud applause. ${ }^{53}$ This incident illustrates the usefulness of the strategy of collaboration with a mate, for without Walter's reputation she would have been unable to borrow the equipment. However, it was her own creativity that enabled her to put together the various pieces to accomplish her goal. This expedition provided another bonus, for on this expedition she met another obligatory amateur astronomer, Mary Evershed, who became her friend. ${ }^{54}$

The BAA's plans to send a large party to Algiers to observe the solar eclipse of 28 May 1900 collapsed when the ship chartered from the Royal Mail Steam Packet Company was requisitioned by the British government as a transport ship to South Africa. The BAA had received about 140 applications for berths, but when satisfactory alternative arrangements could not be made, many cancelled. A number of small parties were nevertheless arranged to observe at different locations. ${ }^{55}$ The Maunders and Walter's two older daughters went to Algiers, where Annie reported that 'we have been more successful than we have dreamed'. ${ }^{56}$

The BAA did not attempt to organize an expedition to observe the total solar eclipse of 1901. ${ }^{57}$ Walter Maunder went as a representative of the Royal Observatory at Greenwich and Annie accompanied him. ${ }^{58}$ The events preceding this eclipse illustrate Walter's uncomfortable relationship with the RGO. In an extensive correspondence with Captain Molesworth, a member of the BAA and a frequenter of its eclipse expeditions, Annie expressed her frustrations. She complained to Molesworth that 'the Astronomer Royal

51 Maunder, Indian Eclipse, op. cit. (49), 1.

52 She also served as a role model for women. Young women who were interested in astronomy had Maunder's accounts in journals available. She encouraged her stepchildren to go on eclipse expeditions. These expeditions were attended by people of all ages, and it is highly probable that Annie Maunder encouraged young girls to attend.

53 The Journal of the British Astronomical Association (1898), 8, 263.

54 'Photographs of the corona, A. S. D. Maunder', in Maunder, Indian Eclipse, op. cit. (49), 107; ibid., 1.

55 E. W. Maunder (ed.), 'The total solar eclipse: 1900', in Report of the Expeditions Organized by the British Astronomical Association to Observe the Total Solar Eclipse of 1900, May 28. RAS Archives.

56 A. S. D. Maunder to Molesworth, Folio 2, Letters 1, 2, and 3. RAS Archives.

57 McKim, op. cit. (40); BAA, Memoirs of the British Astronomical Association (1889), 42, part 1, 53.

58 A. S. D. Maunder to Molesworth, 14 September 1900, folio 2, letter 4. RAS Archives. 
proposes to send my husband to Mauritius on the ground that he is experienced in eclipses and the totality is shorter there, and Mr. Dyson who wants to try long exposure photographs is to go to Sumatra because he is new to the work'.

Annie realized that Walter was being sent to the less than choice site. 'I don't quite follow the logic, but Professor Turner, who worked it out from the Astronomer Royal does, so I suppose it was all right at least as far as the logic is concerned ${ }^{\prime}{ }^{59}$ They almost decided to stay at home, because there was a chance that Walter would get Sir Norman Lockyer's position at South Kensington, where 'he would have good instruments and be able to go in for spectroscopy again ${ }^{6}{ }^{60}$ However, she decided that the chances for the job were not good, as Sir Norman had a son "whom he wants to succeed him. Jimmy is a more amiable youth than his father, but he does not inherit any brains ${ }^{9}{ }^{61}$ Both Maunders went to Mauritius, but without the support of their friends in the BAA.

The next organized BAA expedition occurred in 1905 when the path of totality passed over Spain and North America. Although the BAA expedition went to Spain, the Maunders went to Labrador as invited guests of the Canadian government. However, bad weather spoiled the observing.

The four eclipse expeditions carried out by the BAA represent the best demonstration of what amateurs could contribute to astronomy. Members of these expeditions had seen the eclipsed Sun hidden by clouds and had seen, photographed and drawn three types of corona - one approaching minimum, another nearer minimum and, finally, a maximum. They also had the privilege of hearing their reports read at BAA meetings and seeing their photographs and drawings displayed in the three special eclipse volumes published in 1898, 1900 and $1905 .^{62}$

\section{Relationships with the Joint Permanent Eclipse Committee}

Clearly, amateurs made important observations on these eclipse expeditions. However, the Joint Permanent Eclipse Committee (JPEC) made it apparent that, although it was willing to publish the Maunders' data, the Committee did not want to be bothered by photographs and reports by amateurs unless they 'shall seem to them of sufficient value'. E. H. Hills declined Walter Maunder's offer of photographs taken by BAA observers for 'we have already at our disposal a very good series of negatives'. He did, however, agree 'that the corona photographs taken by you and Mrs. Maunder are of sufficient interest and importance to be included in the final report ${ }^{9}{ }^{63}$ This attitude represented a change from the more egalitarian 1860s to 1880s. As Alex Soojung-Kim Pang notes, during this time eclipse expeditions consisted of a mix of professional and amateur astronomers, colonial officials, army officers and intelligent gentlemen. ${ }^{64}$ By the 1890 s the prestige of amateur astronomy had declined, and the largely amateur BAA was unable to purchase the

59 A. S. D. Maunder to Molesworth, 14 September 1900, folio 2, letter 4. RAS Archives.

60 A. S. D. Maunder to Molesworth, 28 December 1900, folio 2, letter 5. RAS Archives.

61 A. S. D. Maunder to Molesworth, 28 December 1900, folio 2, letters 5 and 6. RAS Archives.

62 McKim, op. cit. (40), 54.

63 E. H. Hills to E. W. Maunder, 20 November 1898. Letter 151, Correspondence of the Joint Permanent Eclipse Committee. RAS Archives.

64 Pang, 'Social event', op. cit. (1), 258-9. 
expensive cameras and spectroscopes obtained by the JPEC. ${ }^{65}$ Most of the BAA members did not have access to the equipment available to the Maunders, and were forced to rely upon drawing rather than photography. This reliance (from necessity) on the 'lower tech' method of drawing rather than photography may also reflect the declining status of the amateur.

Annie Maunder had more prestige than most amateurs both because of Walter's position and because she had established a reputation on her own. The JPEC expressed willingness to appoint her as an official observer. Walter approached Captain Hills, secretary of the committee, gingerly asking him if he thought the JPEC would find it acceptable 'to appoint a lady [Annie] as an official eclipse observer'. Hills responded that he himself did 'not see any reason why Mrs Maunder should not be sent out as an official observer'. He questioned, however, if they would be able to obtain the necessary instruments. ${ }^{6}$

In Annie's reply to Hills, she described the observation programme that she envisioned and noted the kinds and locations of instruments she would need. ${ }^{67}$ Hills, however, delayed his reply to her letter, prompting her to write again: 'I suppose, as I have not heard from you again, that you either have not had an opportunity of suggesting the arrangement that I should go to Mauritius as the JPEC's observer, or the suggestion has not been favourably received ${ }^{6}{ }^{68}$ Hills immediately answered that although he had not yet formally presented her request to the Committee, he would immediately ask for a special meeting and 'if the chairman is opposed to it he can block the question by simply refusing to have a special meeting which cannot be held without his consent' ${ }^{69}$

The meeting apparently never occurred, for in Annie Maunder's reply to Hills she explained that Walter had been unable to locate the necessary prismatic camera. ${ }^{70}$ It is tantalizing to speculate whether the unavailability of the prismatic camera was the actual reason for withdrawing the request, or whether it just represented a way to 'save face' in case the JPEC either refused to have the meeting or had it and denied her request. Even though the JPEC members accorded more credence to Annie Maunder's observations than to others, her status among the élite of the astronomical community (members of the RAS) remained marginal.

Although Annie was without official status, she went with Walter to observe the 1901 eclipse and produced a report of her observations. At the request of the president of the Royal Society, she submitted a report of her independent observations to Hills to be read at a joint meeting of the Royal Society and the Royal Astronomical Society. ${ }^{71}$ To be invited

65 Pang, 'Social event', op. cit. (1), 272-3.

66 E. W. Maunder to Hills, 4 February 1901, Letter 97; Hills to E. W. Maunder, 5 February 1901, Letter 98. Correspondence of the Joint Permanent Eclipse Committee. Box 55.2 (81-100). RAS Archives.

67 A. S. D. Maunder to Hills, 6 February 1901, Letter 99, Correspondence of the Joint Permanent Eclipse Committee. Box 55.2. RAS Archives.

68 A. S. D. Maunder to Hills, 18 February 1901. Letter 104, Correspondence of the Joint Permanent Eclipse Committee. Box 55.2 (101-120). RAS Archives.

69 Hills to A. S. D. Maunder, 10 February 1901. Letter 105, Correspondence of the Joint Permanent Eclipse Committee. Box 55.2 (101-120). RAS Archives.

70 A. S. D. Maunder to Hills, 20 February 1901. Letter 106, Correspondence of the Joint Permanent Eclipse Committee. Box 55.2 (101-120), RAS Archives.

71 A. A. D. Maunder to Hills, 21 October 1901. Letter. 116, Correspondence of the Joint Permanent Eclipse Committee. Box 55.2 (101-120), RAS Archives. 
to have her paper read as a woman and amateur was, of course, an honour, but when the time came to publish the preliminary report, Robert Harrison, the assistant secretary of the Royal Society, questioned whether her report should be published in the Proceedings of the Royal Society and the Monthly Notices of the Royal Astronomical Society along with those of the official observers. ${ }^{72}$ Hills defended Annie by supplying a precedent for including reports of those not sent out by the Committee (Christie's and Dyson's reports on the eclipse of May 1900)..$^{73}$

The problems with the Joint Permanent Eclipse Committee further confirmed the Maunders' convictions that the prestigious Royal Society and Royal Astronomical Society had no place for the contributions of amateurs. ${ }^{74}$ Although they continued to submit papers to the publications of the Royal Society and the Royal Astronomical Society, by far the majority of their works appeared in the Journal of the British Astronomical Association and in its Memoirs.

In addition to her work in solar astronomy (sunspots and solar eclipses), Annie Maunder worked with Walter on the controversial subject of life on Mars and did some work on the aurora and meteors. ${ }^{75}$ One of Annie Maunder's most pervasive interests was in Eastern folklore about the constellations, a pursuit that began early and continued long after Walter's death. ${ }^{76}$ Annie and Walter shared the opinion that amateurs could make important contributions to astronomy. Walter in particular thought that the amateur had an advantage over the professional because of his or her greater freedom. Annie had no choice, so naturally stressed the importance of amateur contributions. Elaborate equipment was unnecessary, for one need not "use a cannon to kill a fly'. ${ }^{77}$ In the jointly authored The Heavens and Their Story, Walter noted in the preface that the book was 'almost wholly the work of my wife'. Hoping to inspire 'the reader ... to study astronomy for himself', the

72 Robert Harrison, Assistant Secretary, Royal Society to Hills, 8 November 1901. Letter 122, Correspondence of the Joint Permanent Eclipse Committee. Box 55.2 (121-140), RAS Archives.

73 Hills to Harrison, 10 November 1901. Letter 123, Correspondence of the Joint Permanent Eclipse Committee. Box 55.2 (121-140). RAS Archives.

74 Although amateurs have played important roles in the Royal Astronomical Society since its inception, the Maunders certainly perceived discrimination within the Society. Even though women were admitted as honorary Fellows from 1835, they were excluded from regular membership until 1915, when Mary Blagg, Fiammetta Wilson, Ella K. Church, A. Grace Cook and Margaret T. Meyer were elected Fellows. Kidwell noted that threequarters of the British women astronomers in her sample were members of the BAA, and that these women published more frequently than did women Fellows of the RAS. See Kidwell, op. cit. (14).

75 For Maunder's work on Mars see, for example, A. S. D. Maunder, 'Report of the meeting of the British Astronomical Association', The Journal of the British Astronomical Association (1922), 32, 217-21; E. W. Maunder and A. S. D. Maunder, 'Some experiments on the limits of vision for lines and spots as applicable to the question of the actuality of the canals on Mars', ibid., 13 (1903), 344-51 and A. S. D. Maunder, 'The highways and the waterways of Mars', Knowledge, new series, 4 (August 1907), 169-71. For her work on meteors and the aurora, see A. S. D. Maunder, 'The meteor and aurora observing sections and the upper atmosphere', The Journal of the British Astronomical Association (1924), 34, 23-8.

76 See, for example, A. S. D. Maunder, 'Iranian migrations before history', Scientia (1916), 19, 115-24; 'Astronomical allusions in sacred books of the East, being a paper read before the Victoria institute at the 567th Meeting, held April 12th, 1915', Girton College Archives; 'When the snow-white bull with gilded horns ushers in the year', The Journal of the British Astronomical Association (1931), 41, 127-33; and 'The four star champions of Iran', ibid., (1931), 41, 425-9.

77 E. W. Maunder. Guide to the Constellations, and Introduction to the Study of the Heavens with the Unassisted Sight, London, 1904, p. iii. 
Maunders stressed that it was unnecessary 'to be a rich man, and to build a great observatory, in order to become an astronomer' ${ }^{78}$

\section{Conclusion}

Forbidden professionalism by her gender, Annie Maunder was compelled to be an obligatory amateur. But rather than resenting this niche, she took advantage of the situation to become an advocate of the amateur. Possessing all the requisites for professionalism except the correct gender, she was not just an adjunct to Walter but an important contributor to astronomy in her own right. If she had been a man, she probably would have become a professional, for her contributions to science were on a par with those of many professional men. Her obvious astronomical competence gained from formal university training and being a paid assistant at the Royal Greenwich Observatory, and from informal training by her husband, made her scientific work entirely respectable. As editor of the Journal of the British Astronomical Association from 1917 until 1930 and a member of both the exclusive Royal Astronomical Society (elected 10 November 1916) and the British Astronomical Association, Maunder's pronouncements had more credibility than those of most amateurs. It seems apparent that she possessed all of the characteristics which constituted a professional with the exception of paid employment. Her short-term, poorly paid job as a computer might qualify her on this count as well. She published articles not only in the Observatory, the Chaldean, Scientia and Knowledge but also in the Journal of the British Astronomical Association and in the prestigious publications of the Royal Astronomical Society. As an obligatory amateur, she was allowed to do certain things but was prohibited from doing others. The fact that she had a spouse who was disenchanted with the astronomical establishment yet could operate within it when necessary was also beneficial to Annie's career. Walter could and did arrange for her to borrow equipment and got her writings a hearing, denied to others, before professional organizations. Yet although Walter acted as a facilitator, Annie was interested in astronomy before she met him, and her interest continued after his death.

Annie Maunder's success as a propagandist for amateur astronomy is clear from the reception of her co-authored book. The reviews of The Heavens and Their Story were very favourable. One reviewer noted that 'the whole book is written with a lucidity and a consideration for that dull, unobservant person that speaks volumes for the care that $\mathrm{Mr}$. and Mrs. Maunder have bestowed upon the compilation of their work' ${ }^{79}$

Annie Maunder's prodigious output makes her unusual, but not unique, among contemporary women astronomers. Another obligatory amateur, Agnes Clerke, for example, published one very popular book, A Popular History of Astronomy during the Nineteenth Century (Edinburgh: Black, 1885) and other widely read books on astrophysics. In addition, she published numerous articles in the Edinburgh Review, articles relating to astronomy for the Encyclopaedia Britannica and the Dictionary of National Biography, and reviews for the Observatory Magazine. Margaret Huggins's early interest in

78 A. S. D. Maunder and E. W. Maunder, The Heavens and Their Story, London, 1908, preface.

79 'New books and memoirs', review of Maunder and Maunder, op. cit. (78), The Journal of the British Astronomical Association (1909), 19, 357-8. 
spectroscopy indicates that she too may have been an obligatory amateur, although when she was the sole author her publications tended to be in the history of science. When she co-authored works with her husband William they were observational and theoretical. Mary Evershed published a significant paper on solar prominences in the Monthly Notices of the Royal Astronomical Society (1913) and numerous other astronomical works including Southern Stars: A Guide to the Constellations Visible in the Southern Hemisphere (London 1896). Mary Blagg worked on lunar nomenclature and was involved in a study of variable stars when H. H. Turner used her as a volunteer to reduce the raw data. She published a series of ten papers in the Monthly Notices.

Annie Maunder's basic mathematical training, thoughtful publications, editing of journals and membership of professional organizations make it clear that she was a full participant in the astronomical community. Only one factor precluded her from becoming a professional: her gender. Annie Maunder was joined in these qualifications by other astronomers. As we have seen, the term professional as usually defined does not apply to women such as Maunder, Clerke, Blagg, Evershed, Huggins and other nineteenth and early twentieth-century astronomers, for they had no opportunity to choose between amateur and professional status. Since neither term adequately described the work of these women, I proposed the term obligatory amateur as an alternative. Annie Maunder's life and career justifies the need for a new expression to describe the lack of choice available to these astronomers. 